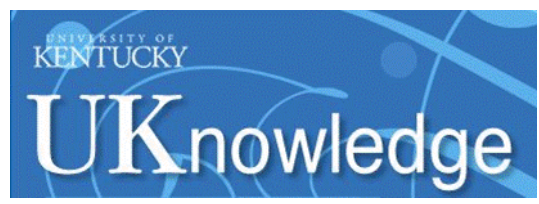

University of Kentucky

UKnowledge

Law Faculty Scholarly Articles

Law Faculty Publications

January 2012

\title{
A Library is Not the Books: An Ethical Obstacle to the Digital Library
}

James M. Donovan

University of Kentucky, james.donovan@uky.edu

Follow this and additional works at: https://uknowledge.uky.edu/law_facpub

Part of the Library and Information Science Commons

Right click to open a feedback form in a new tab to let us know how this document benefits you.

\section{Repository Citation}

Donovan, James M., "A Library is Not the Books: An Ethical Obstacle to the Digital Library" (2012). Law Faculty Scholarly Articles. 439.

https://uknowledge.uky.edu/law_facpub/439

This Article is brought to you for free and open access by the Law Faculty Publications at UKnowledge. It has been accepted for inclusion in Law Faculty Scholarly Articles by an authorized administrator of UKnowledge. For more information, please contact UKnowledge@lsv.uky.edu. 
A Library is Not the Books: An Ethical Obstacle to the Digital Library

This article is available at UKnowledge: https://uknowledge.uky.edu/law_facpub/439 


\section{A Library is Not the Books: An Ethical Obstacle to the Digital Library James M. Donovan}

\section{Introduction}

Casual and thoughtful speakers alike frequently use "library" as though it were the collective noun for "book": A herd of cows, a murder of crows, a library of books. In practice it matters little whether "book" is understood as a specific physical artifact of ink and paper, or whether it refers more generically to any information-containing entity. The consistent point appears to be that in the presence of a sufficient number of those items, a library necessarily rises into existence.

This implied relationship proves critical to debates over the implications of digital formats for libraries. If libraries are reducible to their books (however understood), then a fundamental change in books requires a similarly radical reaction from libraries. In that view, to the extent traditional books themselves are an endangered medium, then so too must be libraries, given that they are mere "warehouses" of books (Sandler, 2005, p. 16). To resist such inevitable changes not only betokens an unhealthy conservatism, but worse, an irrational denial of the fundamental relationship between books and libraries.

This article, however, offers three independent demonstrations that libraries cannot be reduced to their books. The library is not an additive category, but rather an emergent concept greater than the sum of its parts. Books may typically and traditionally serve as building blocks for libraries, but the presence of books of any definition is not sufficient for something to be recognized as a "library."

Breaking this link raises serious consequences for the format debates. If physical books do not make the library, then less so can digital books. The challenge will then shift to identify what must be present to create a library other than information-containing entities, and then to inquire whether these additional 
qualities can be achieved in the digital environment. The "digital library," in other words, remains to be proved as an intelligible idea, whatever its technological possibility. The conclusion offered here is that such alchemy is not impossible, but highly unlikely.

\section{The Logical Argument}

The first demonstration follows from a common argument advancing the case for the digital library that may be synopsized in the following form: Libraries contain books, and books are now increasingly preferred in digital format; because digital books offer significant advantages over traditional paper volumes, libraries that make this change in their collection development will likewise be better libraries to meet the informational needs of their patrons (Arms, 2000, p. 4; Singer, 2011).

Framed in this manner, the argument asserts an especially overt claim that libraries are reducible to contents literally or euphemistically called "books." Given that basis, the background assumptions that changes in format would be costless in terms of information and that digital files are more useful than physical tomes, lead to the conclusion that digital libraries are inherently superior to their brick-andmortar predecessors.

This is a fairly easy stance to critique. The contrarian arguments tend to focus on two worries. The first objection denies that multiple copies are always redundant. Libraries do not contain fungible versions, but particular items bearing special information reflecting the history of its local use (Manguel, 1996, p. $15-16 ; 2010$, p. 196). The fear is that this unique dimension will be lost when singular copies are discarded in favor of a digital exemplar selected to serve as "the" copy.

The second, broader concern challenges the assumption that format conversion can occur without information loss, suspecting instead that the total digital outcome will contain less than exists in the physical original. Inevitable loss of content will occur during the transition, not least as some items are judged of insufficient interest to warrant the expense and trouble to digitize (Jeanneney, 2007, p. 73). 
The migration from manuscript to codex inflicted a similar loss from which our heritage has never recovered. Today we witness a similar shortfall in the migration from VHS to DVD. We would be prudent to avoid such decimation of our intellectual patrimony.

Those are both valid issues, but as objections they imply that the pro-digital argument is somehow erroneous, or at least overinflated. If we knew the true costs and ramifications of the envisioned conversion, it seems to say, fewer librarians would rush to compost the collections entrusted to them by previous generations. But we can grant everything claimed in the case for digitals and then ask a different question, one that then wonders whether, in even that most favorable context, there still might not be some reason to remain wary of the all-electronic future.

The pro-digital argument prioritizes the book and its informational content as the relevant unit for this discussion, with little explanation as to how these relate to the library that contains them. Seemingly the two are equivalent, with libraries being nothing more than aggregates of books. Digital defenders then move from this premise to another involving the benefits that accrue with a change of formats, to reach conclusions about improvements in the libraries that contain them: Electronic libraries will contain and do everything traditional libraries have and do, only more, better, faster. Without that promise, the effort and cost to convert formats - not only in money but also patron confusion - would offer little return on investment. Unfortunately the two claims supporting that tempting result are incompatible. It cannot both be the case that libraries are their books, and that digital libraries are superior to traditional ones.

If we accept for the moment the assertion that libraries are reducible to the books they contain $\left(B_{i}=L_{b}\right)$, and add to that the concession that the universe of digital information will be the equivalent of its paper original $\left(D_{i}=B_{i}\right)$, then advocates are indeed justified in their assurances that libraries would suffer no informational loss through the substitution $\left(D_{i}=L_{d}\right.$; therefore $\left.L_{d}=L_{b}\right)$. But note that under this reasoning 
they also accrue no benefits, which is what advocates really want to be able to claim (i.e., that $L_{d}>L_{b}$ ). Some part of the digital argument must be flawed.

We must continue to entertain the strong claim that the transition to digitals will be costless in terms of the total universe of information - a needed premise to avoid the two objections of the negative and practical type mentioned earlier. To maintain the conclusion that the change will render improvements to libraries, these advocates cannot assert a belief that libraries are reducible to their information units. That is, $B_{i}=D_{i}$, but because $B_{i} \neq L_{b}$ and $D_{i} \neq L_{d}$ it becomes reasonable to posit that $L_{d}>L_{b}$. Whether the result is true or not is another matter, but at least the conclusion is no longer self-contradictory.

The digital advocate's argument for format conversion, therefore, is intelligible only if we assume that libraries of asserted similar informational content are not themselves similar, meaning that libraries are not reducible to the information they contain. To the extent that "books are indeed primarily the information they contain" (Gomez, 2008, p. 23), libraries are not reducible to their books.

This may seem an unproblematic concession, until we realize that we have few conceptual tools to fill the gap. If libraries are not books, what then are they? While many librarians may have their favorite tropes to invoke, the present task is to derive an answer through reasoned analysis. What do the facts support? We come closer to seeing one possible response in the next section, which looks for deeper understanding of libraries through the ways in which we talk about them.

\section{The Semantic Argument}

We would be foolish to deny that books are the core meme around which libraries coalesce. Even digital alternatives are parasitic on the tradition of the book. They are called e-books after all, and strive to mimic the experience of the physical volume. The previous section severed the broad equation between libraries and their books, but did little to highlight the actual nuances of that relationship. To address 
this need we turn to the ways that we talk about libraries. Specifically, what are the rules to properly name something a "library"?

Words can be assigned meaning through various mechanisms. Pointing, for one: I can define "cat" by speaking the label as I point to a specific example of the category. Stipulation is another technique: a "cat" is simply whatever I say a cat is. Neither of these methods help us much to learn what it means that something is a "library." A more productive approach is found in Ludwig Wittgenstein's claim that "the meaning of a word is its use in the language" (Wittgenstein, 2001, §43).

To understand Wittgenstein we can contrast this position with his own earlier discussion of language in the Tractatus. In that work he insisted that "Most of the propositions and questions of philosophers arise from our failure to understand the logic of our language" (Wittgenstein, 1961, §4.003). He believed that the surface manifestations of language are messy, confusing, and inexact, as likely to hide the speaker's meaning as communicate it. The work of philosophy (and of the analytic philosophers particularly, especially after Bertrand Russell) is to unmask the logical structure hidden beneath any particular utterance. The unearthed structure reveals the true meanings with exacting precision, eliminating whatever ambiguities have crept into the surface phrases. The concern to map out this deep structure reaches such a level of precision that a properly executed analysis might easily be confused with a mathematical proof. In the Tractatus Wittgenstein had suggested that most philosophical debates arise out of a failure to properly attend to this logical structure of language, and are therefore more misunderstandings of language than true problems.

Wittgenstein retains this conclusion that most philosophical discussions are semantic puzzles and not genuine problems, but in the subsequent Philosophical Investigations he inverts the analysis. The surface appearance of language-what people actually say-is no longer characterized as an inept communication of a deeper, more authentic structure. Instead, these statements are exactly what they 
appear to be, which is to say, performances conforming to the particular language context within which the sentence occurs. A word or phrase derives its meaning from the use, not from anything embedded within the utterance, much less in the heads of the speakers: "nothing is more wrong-headed than calling meaning a mental activity!" (Wittgenstein, 2001, §693).

According to Wittgenstein, language can be analogized to a game such as chess, which people play together according to known rules (Wittgenstein, 2001, §7). If language has this nature of being a kind of game, then it would follow that the meaning must be tied to the social context in which it occurs, rather than being an abstract property that inheres in the statement or term itself.

We know this to be true of some specific examples. For example, consider this sentence from a recent news article: It is "unfair, shortsighted to restrict state aid to for-profit schools." This can mean either that state money should not be limited to for-profit schools or that state money should not be withheld from for-profit schools. In other words, it can mean either one thing or its opposite, and the surface statement does not allow us to distinguish between them. To learn this we must look not to diagrams or symbolic restatements of the sentence's structural relationships but to the context, which tells us that the second rendering is likely the intended meaning. Wittgenstein would extend this principle to the whole of language. To know meaning requires placing the uttered statement in social context, allowing us to identify the work it was intended to accomplish.

This insight can help untangle the challenge to discover what it means to refer to something as a "library." By extracting the rules for proper use of the term in ordinary talk we should be able to draw conclusions about the meaning of "library." If the discovered meaning of "library" exceeds that which can be encompassed by "books," then of necessity the former cannot be wholly reduced to the latter. This outcome would not only replicate the conclusions previously achieved, but also offer tools to understand why this nonequivalence applies even though many people believe otherwise. 
We can imagine different approaches to the task. The method employed here seeks to isolate the important attributes of one term by contrasting it with other, closely related terms. Whether conceived in terms of de Saussurian-derived semantic structuralism (Culler, 1976, pp. 8-50) or Roschian prototype theory of categories (Lakoff, 1987, pp. 39-57), the broad idea is that words-and more importantly, the concepts to which these words refer-are best understood not in isolation but through the network of interrelated and often overlapping terms in which they are embedded.

Candidate contrasting terms are suggested in the following extract:

What's the difference between 600,000 fabulous digital pictures of things chosen somewhat haphazardly, and the same number of equally fabulous things that reflected a policy and design? It's the difference between a storehouse of books and a library; a bunch of old stuff about baseball and the Baseball Hall of Fame; walls full of impressionist art and the Musée d’Orsay. (Johnson, 2010, p. 188)

"Storehouse" is one of several possible quantity terms to indicate a large or significant number of books. If libraries were equivalent to their books, then any sufficiently large accumulation of books could meaningfully be called a "library." At the other end of the spectrum, though, we find that a single book can be called a library only when speaking ironically. Most libraries therefore contain books in quantities greater than one, seeming to raise the question as to how many are actually needed to effect this transformation from a pile of books to a library. At what point does the reference cease to be ironic, and instead become literal?

Framed in this manner, the problem to relate libraries to their constituent books might be approached as a version of the sorites paradox. "Sorites" is Greek for "heap," and refers to the classic philosophical challenge to identify the precise moment when a pile of sand grains becomes a "heap" (Hyde, 2005). We know that one grain does not a heap make, while one million certainly do. But when did the transition 
occur? Is there one grain whose presence or absence makes the difference? We can similarly ask whether books relate to libraries the way grains relate to heaps. If a single book is not a library, is there one book but for which a pile of books does not merit the label?

Deeper reflection reveals that our problem is not a variation of the sorites paradox. Unlike grains of sand, which necessarily become a heap when enough are added together, books do not inevitably become a library merely by increasing the number. Our language recognizes the existence of sizeable accumulations of books, for example in bookstores and storehouses, yet to call these "libraries" invites certain correction. We escape the problem of the sorites paradox by noting that we can add books ad infinitum without necessarily ever achieving a "library." In the rejection of the sorites paradox we find a second proof that libraries are not their books.

We can press the method yet further to explain this result. If book numbers are insufficient to create a library, a different attribute must regularly co-occur with books in order to mark the semantic recognition that this heap of books is a library, while that one (with just as many books) is not.

One feature that appears to be required is intention. Libraries are always deliberate acts. There are no accidental libraries. This inference follows from their being attached to specific responsible parties (The New York Public Library, Jim's library, the Library of Congress) or circumscribed by topical filters (the library of movie DVDs, the law library). Both limitations demonstrate that not just any book can be counted toward the library, but only those that have been chosen by the organizer (the first condition), that fit the specified subject matter (the second condition), or both: Jim's library of anthropology, the university 's local history library.

Book heaps, by contrast, are fundamentally accidents, however large, whereas libraries are intentional creations, however small. Heaps may be comprised by the same "stuff," that is say, books. But whereas 
books haphazardly accumulated are not called "libraries" (again, without irony or sarcasm), libraries are understood to refer to conscious acts of identifiable agents, as illustrated by the following:

"Libraries are not neutral depositories of printed materials-a kind of black box in which readers and texts 'only connect.' Libraries are social systems, the outcome of the intended and unintended actions and policies of those who work in and for them, and of their users." (Pawley, 2007, p. 265)

"[A]ny library, by its very existence, conjures up its forbidden double; an invisible but formidable library of the books that, for conventional reasons of quality, subject matter or even volume, have been deemed unfit for survival under this specific roof." (Manguel, 2006, p. 116)

"a library, considered not as a collection of objects that happen to be books but as a number of books that have been chosen to constitute a library, is an extraordinary thing." (MacLeish, 1975, p. 230)

While intentional selection is necessary, it is not a sufficient criterion to distinguish the library from all other book accumulations. To see this we must contrast "library" with a third term, the "collection."

"Collections" also refer to intentional acts that bring books together. The intention needed here is not to acquire a specific book, but to acquire it because of its relationship to other, already owned books. To cross that demarcating line, "In an instant, an accumulation becomes a collection" (Baxter, 2002, p. 8). While sharing this feature, however, collections still are not quite libraries. Consider the following two invitations:

- Would you like to visit the art library?

- Would you like to visit the art collection? 
What you might expect to see upon accepting the first is not the same as with the second. Here, at least, "library" and "collection" are not interchangeable. The distinctiveness of these two terms can be further highlighted by noting that they relate through verbs of possession rather than equivalence:

- The library has an art collection (always acceptable)

- The library is an art collection (usually not well-formed)

Also:

- The art collection is in the library (always acceptable)

- The library is in the art collection (usually not well-formed)

The difference marked in the latter pair is that while the collection may be part of the library, the library is not actually part of the art collection, although it may be in the room with it. Taken together, these contrastive pairs suggest that "library" is a hierarchically inclusive concept to "collection." Libraries may contain collections, while collections rarely contain libraries. Granted that collections and libraries can both be book aggregations, we have yet to specify what differentiates the library from a mere collection.

Some insight into this final matter can be gleaned by imagining a library deconstructed into its collections. A library, for example, may move its holdings from the shelves into a warehouse after boxing for storage. We would not comfortably refer to the relocated books as the "library," but now only as the "books from the library" or some similarly descriptive phrase. In the two instances, though, the books are exactly the same, and chosen with identical intentionality. The change has been effected by the loss of two features thought essential to the idea behind a properly named "library": first, order and accessibility of its materials, and second, the rebuttable presumption that those materials are available for use by and loan to the patron. 
A collection of books in itself, no matter how large, is not necessarily a library, but when those books are well selected, arranged in some logical order, cataloged or not, but usable by the owner and/or by others, then they constitute a library and deserve recognition as such. (Harris, 1999, p. 170)

Books, collections and libraries may in some mundane sense all be of the same stuff, but only in the same sense as carbon, coal and diamonds. What distinguishes them is not what they are, but how that material is organized and internally arranged. Rationalized structure makes all the difference. It determines a thing's essential nature.

We can summarize this section with the following: Ordinary language use shows that libraries are not created through the accumulation of books. Rather, aggregations or "heaps" of books can be distinguished from libraries and collections through the intentionally selective acts behind the latter. Moreover, these may be further distinguished in that while collections are intentional, libraries are both intentional and ordered.

\section{The Ethical Argument}

The previous sections identified the structural and procedural elements that set libraries apart from visibly indistinguishable heaps of books. That result suffices to sever the conceptual reductionism between libraries and their books, but it leaves unfinished the larger project to capture fully the unique qualities that characterize the library. This section argues that the emotional concomitants of libraries follow from their need to organize contents and the additional values libraries thereby capture and come to embody.

Observers have written that libraries inspire deep emotional reactions from people. The phenomenology of libraries inspires a sizeable literature expressing authors' relationships to the traditional book. Examples include the several volumes by Alberto Manguel (2004, pp. 16-17; 2006; 
2010, pp. 267-269) and Nicholas Basbanes (1995, pp. 5-6; 2005, pp. 69-88), as well as contributions by Larry McMurtry (2008, p. 8), Susan Hill (2010, p. 202), and Pat Conroy (2010, p. 111). Other books recount true tales of deep bibliomania that lead to extraordinary criminal acts (Bartlett, 2009, p. 47), and still others employ this theme to create fictional worlds, including a manga title (Yumi, 2010, pp. 1517) and a mystery series (Dunning, 1992, p. 6). In short, people have a history of deeply affective ties with the traditional book. It is so far unclear whether electronic files shall prove able to provoke a similar profession of devotion.

While books have an undeniable attraction, this emotional resonance engulfs libraries in ways that are not tied directly to the included books. Buildings we erect to house our libraries aim deliberately to inspire what Rudolf Otto (1958, pp. 5-7) termed an experience of the numinous. Thomas Augst (2007, p. 150) points to the "'ecclesiastic architecture' of libraries" and their role as "'secular cathedrals' of liberal society." Libraries, in other words, often pass as close as anything in our secular society to sacred spaces (Battles, 2003, p. 119; Powell, 1958, p. 204; Kelman, 2001, p. 29).

Kiersten Latham (2009, p. 139) identified four themes of this numinous encounter:

First, the experience can be seen as a holistic uniting of emotions, feelings, intellect, experience and object.... Second, the object plays a central role in the experience, linking the experiencer to the past through both tangible and symbolic meaning. Third, the person feels as if he or she is being transported to another time and place, affecting the experiencer temporally, spatially, and bodily. And finally, deeply felt connections are made with one's self, the past, and spirit that communicates [sic] to others and endures throughout a person's life.

Although writing in the context of museums, Latham's conclusions transfer well to libraries, and not merely because of their shared historical origins in the Greek mouseia (Lerner, 1998, pp. 24-32). Descriptions can be found of encounters with physical books in identical terms: 
[The] imagination of the students is kindled by making contact with original works in ways that never happens when they merely see them as reproductions. They respond not just to the content, but everything about the work that conveys the texture of the past-typography or calligraphy; engravings and lithographs; autograph signatures; and even (or especially) wills and contracts which seem to yield up, almost inadvertently, the daily fabric of a distant culture. (McDade, 2006, p. 116)

Such emotional connection with the physical document, even amidst the availability of electronic facsimiles, attaches not only to ancient artifacts. Nicholas Basbanes (2003, p. 295) recounts the same reaction to the printed edition of the notorious Starr Report.

The numinous encounter is "more than narrative, more than physical: it is a lived experience that involves imagination, thoughtfulness, spirit, and feelings as much as it does knowledge and information" (Latham, 2009, p. 155). The museum and the library thus serve as sites "for the formation of personal values" (Latham, 2009, p. 152), a conclusion we would amend only to assign the library as well a role to instill civic virtue.

Latham suggests several explanations for our reflexive awe and excitement upon entering a library. The ethical aspect that interests us flows from the conclusions of the previous section. Libraries, we found, may be characterized as a heap of books whose members are intentionally selected and rationally organized. Both of these attributes merit additional discussion, and we begin with the latter.

Library organization can serve multiple functions, and certainly the one uppermost in the minds of librarians concerns easing discovery of specific items by interested patrons. The method we choose to achieve that end, however, is not neutral. 
An obvious illustration is Melvil Dewey's decimal classification system (Battles, 2003, pp. 138-139). His express goal was to create a structure sufficiently flexible to encompass the whole of human intellectual endeavor. The system allowed books to be placed on shelves based upon their disciplinary relationships to one another, rather than in order of accession or alphabetical arrangement. Systemic classification achieves the goal of facilitating item location by establishing hierarchies and preferences for ambiguous cases. These choices encode values and assumptions about information describing the world.

Within such systems the full meaning of a book cannot be found within its own pages. Echoing Wittgenstein's emphasis on context, Rebecca Knuth (2003, p. 29) points out that "the value of any one piece of information often depends on comparison, verification, or contextualization with other pieces." We must learn to what earlier works a book is responding, what pieces of its popular milieu it includes and takes for granted, and so on. Some of these answers concerning a volume's intellectual significance can be given through decisions on where the book should be placed within the library.

Organization does not simply arrange books helpfully on the shelves. It influences our perception of the book through two related impacts. The first concerns the overt organizing principle itself, and the choices we make from among the offered options when inserting a new volume into the collection. Those choices change how we perceive a given title, what we expect to find there, and thus what we actually find:

Filed under Fiction, Jonathan Swift's Gulliver's Travels is a humorous novel of adventure; under Sociology, a satirical study of England in the eighteenth century; under Children's Literature, an entertaining fable about dwarfs and giants and talking horses; under Fantasy, a precursor of science fiction; under Travel, an imaginary voyage; under Classics, a part of the Western literary canon." (Manguel, 1996, p. 199) 
In my own experience the key example of this difficulty concerns the classification of the Don Juan books by Carlos Castaneda (1968). Are they social science (in which case they are meant to be actual accounts), philosophy (in which they should be read as enlightening metaphor), or religion (wherein they should be consumed as arguments to inspire committed belief)?

Given the boundaries of the physical volume, some choices must be made. The book must go somewhere. More than a few critics follow David Weinberger's (2007, pp. 2-7) view that this limitation is a weakness of traditional books, and one that we would do well to abandon. But we should move cautiously in any such direction. The need to make organizing choices may be one of the library's unique strengths; it is perhaps this work that best captures the essence of the library.

The second organizational outcome that influences the reader's encounter with a book concerns the new addition's neighbors on the shelf. A relevant question to ask of any book in a library is "why this one?" Libraries will, after all, always exclude more books than they can ever contain. A complete answer to that question will refer not only to the literal contents of the book, but also how it fits with other titles within the collection. Books "get their value from the way they coexist with the other books a person owns" (Fadiman, 1998, p. 153).

From every book invisible threads reach out to other books; and as the mind comes to use and control those threads the whole panorama of the world's life, past and present, becomes constantly more varied and interesting, while at the same time the mind's own powers of reflection and judgment are exercised and strengthened. (Haines, 1975, p. 143)

This semantic tapestry, reveals John Budd (2008, p. 235, quoting Michel Foucault), "'grows among signs, from book to book, in the interstice of repetitions and commentaries; it is born and takes shape in the interval between books. It is a phenomenon of the library.'" If true, this means that such revealed truths 
will vary from library to library, that the meanings communicated by one collection of books must differ from every other.

The represented worldview is necessarily parochial because it emerges out of accumulated selection choices and placement decisions. But for all its idiosyncrasies, the outcome is rarely arbitrary. For this reason a library bears a special relationship with the person or community it is designed to serve. It reflects their preferences and understandings in a way that another library will not. We see again that there are no generic libraries, but only specific libraries attached to particular persons and communities.

The insight is that the library is a rooted in the local, not the universal. Libraries are not imperfect incarnations of a Platonic ideal Library, but quite the reverse. The library exists in its fullest, most complete sense when it is tied to the histories, opinions, and expectations of an identifiable community. As that community becomes more diffuse and abstract, the final, reifying achievement of the library becomes more uncertain.

To restate the argument, in order to achieve the goal of making materials accessible to the patron, the library organizes them in a way that makes sense at a fundamental level. It maps a local understanding of reality that transcends any individual item or even the sum total of the contents. Through this organization the library transmutes piecemeal information into a general, rationalized cultural knowledge.

Here we reach the final phase in our journey to understand the library. While it has often been asserted that the library is more about knowledge than information (Crawford and Gorman, 1995, p. 5; Herring, 2005, p. 43), we are now able to deconstruct that claim. Libraries are defined through imposing selection and organization upon books (however understood), and the consequences of those processes create a local model of reality and shape meanings to the end of instantiating cultural knowledge. When citizens approach their libraries with a sense of respect and even reverence, it is because they recognize, 
at some level, that libraries reflect back upon them all that they believe about themselves, and most especially all that is good. By its nature as synthesizing process upon multivocal and transtemporal perspectives, the knowledge embodied by the library is qualitatively different from that which can be contained within any book, or even any several books lacking the necessary organizational arrangement. This realization forms the third and final argument that libraries are not reducible to their books.

\section{The Possibility of the Digital Library}

Armed with this result we are now equipped to consider briefly the context in which the problem of the irreducibility of libraries to their books has most recently been raised. Granting this understanding of the "library," what are the prospects for a digital version?

Our attention shall be restricted to the least ambiguous case. Projects such as Google Books inspire a vision of complete digital access to "a comprehensive, searchable, virtual card catalog of all books in all languages" (Google, 2011). This result will be achieved by scanning the complete contents of each book, allowing the text to be searched by keyword. Metadata may or may not be added to enhance access. Assuming Google or someone else actually achieves this goal, the question to ask is whether the resulting database qualifies as a "library."

The project's goal of comprehensiveness precludes the criterion of selectivity, which is one of the two bedrocks of the ordinary language meaning of "library." Whereas print titles have been typically collected one at a time, libraries often access electronic titles in bulk, increasing the likelihood that digital holdings contain much less diversity between libraries. When praised that "One digital library fits all" (Baker, 2001, p. 240, quoting Randy Silverman), this same uniformity breaks the posited individualized relationship of a library to its community, rendering the once sacred encounter with the community's collective self-representation into a brush with a homogeneous information commodity. 
While failing on this first criterion, the possible digital library initially appears to fare better on the second. Means exist to allow discovery by users of the database contents, usually through keyword searching. But while few would argue that the digital tool contains more sheer information than any physical library, the challenge is whether its organization fosters the expression of any broader worldview, or whether it remains little more than the infinite heaping of individual pieces. "Can we," in the words of one skeptic, "Google our way to wisdom?" (Jackson, 2008, p. 155).

Unfortunately the very features that make the digital library conceptually attractive-ready access to heretofore unimaginable quantities of information-may preclude the higher-level processing required to transmute data into knowledge. The problem is not merely that without physical volumes to arrange the virtual library cannot offer a mapped representation of a coherent worldview. Although we do expect that of a library, we should not assume that some programmed facsimile of that experience cannot be mimicked through metadata and display options. Our attention should linger, rather, on the more intrinsic limitations of the format than on possibly transient technological shortcomings.

For information to become knowledge in the manner previously described, materials must not only be organized, but they must be perceived to be organized. To find a book within a physical library, the patron processes this added context on at least some level. She will find a particular call number, and scan the shelves until the specific book is found.

Even if comparable metadata are added to digital files, the patron need never encounter them. In this sense, at least, the user cannot infer a higher organizing principle than the base keyword searching used to find the single text. Opportunities to experience the database as a representation of a specific coherent worldview are thus limited even where the effort has been exerted to replicate that perspective in the electronic environment. Further, were such metadata able to create a shelf-like display of titles in response to a specific query-for example, pulling together all the books on Buddhism 
within the database, from all subject areas, allowing the user to virtually browse the hits-this experience would not reflect the incremental accretion of communal perspectives, but only a private one related to a temporary interest. Such ephemeral outputs are unlikely to elicit the undertone of respect that pervades the encounter of a physical library.

In this crucial sense the overall experience of the user in the digital "library" will differ qualitatively from that offered by the traditional library. This result compels agreement with Michael Gorman's judgment that "there is good reason to ask if the word "library" is applicable in any sense when talking about the "virtual library" (Gorman, 2000, p. 34). The strong version of the digital project in which the goal is to be universal and all-inclusive fails to satisfy the criterion of selectivity. Nor can it provide the preconditions necessary to allow the database itself to become an expression of human intellectual accomplishment which is essential to the phenomenal experience of library-ness.

For these reasons we should withhold that term of high praise from these digital endeavors. The comprehensive digital library by its very nature cannot fulfill our expectations of libraries. We may remain agnostic on the status of less expansive projects, which should be judged on their individual abilities to satisfy the necessary criteria. For the reasons given, however, these are likely to form valuable collections, but not libraries, a distinction whose significance should by now be apparent.

\section{Conclusion}

Libraries are not their books. This point has been defended with three different arguments. First, maintaining that reductive equation renders incoherent the assertion that digital equivalents will produce a superior library for patrons. Second, if libraries were merely their books they would be conceptually indistinguishable from other book aggregates. And third, books alone are incapable of generating the higher-order encounter we can experience when in the library. 
Our confidence in the conclusion is heightened by the way in which the separate demonstrations buttress one another. We compensated for the limitations of any individual method by using three different approaches to reach the same conclusion: books alone do not make a library. The outcome of the second analysis - that libraries are distinguished from heaps and collections by being deliberate selections that are organized-served as a premise for the third, allowing us to argue that selection and organization work to construct the reflected cultural knowledge which inspires the ethical attachment to libraries. The results of the third argument in turn explain a fact offered in the second, namely the ironic use of the term "library." Libraries acquire their cultural significance through the interaction of plural independent works to collectively present an account of local knowledge. One book can thus never be referred to as a library because it cannot offer more than it singularly is.

These demonstrations allow us to render judgment on some versions of the project for a "digital library." At least in the comprehensive varieties the final product will lack essential elements necessary to our idea of what it means to be a library. The outcome can be useful and perhaps inevitable, but will be a library only by analogy. To lose sight of that gap puts at risk the benefits we enjoy from true libraries. If libraries disappear, it will not be because they have been "replaced" by digital analogues, but because we no longer deem important the intrinsic, irreducible values represented by the library.

\section{References}

Arms, W.Y. (2000), Digital Libraries, MIT Press, Cambridge, MA.

Augst, T. (2007), "Faith in reading: Public libraries, liberalism, and the civil religion," in Augst, T. and Carpenter, K. (Eds.), Institutions of Reading: The Social Life of Libraries in the United States, University of Massachusetts Press, Amherst, MA, pp. 148-183.

Baker, N. (2001), Double Fold: Libraries and the Assault on Paper, Random House, New York, NY.

Bartlett, A. H. (2009), The Man Who Loved Books Too Much: The True Story of a Thief, a Detective, and a World of Literary Obsession, Riverhead Books, New York, NY. 
Basbanes, N. A. (1995), A Gentle Madness: Bibliophiles, Bibliomanes, and the Eternal Passion for Books, Henry Holt, New York, NY.

Basbanes, N. A. (2003), A Splendor of Letters: The Permanence of Books in an Impermanent World, HarperCollins, Boston, MA.

Basbanes, N. A. (2005), Every Book Its Reader: The Power of the Printed World to Stir the World, HarperCollins, New York, NY.

Battles, M. (2003), Library: An Unquiet History, W.W. Norton, New York, NY.

Baxter, J. (2002), A Pound of Paper: Confessions of a Book Addict, Thomas Dunne Books, New York, NY.

Budd, J. M. (2008), Self-Examination: The Present and Future of Librarianship, Libraries Unlimited, Westport, CT.

Castaneda, C. (1968), The Teachings of Don Juan: A Yaqui Way of Knowledge, Pocket Books, New York, NY.

Conroy, P. (2010), My Reading Life, Doubleday, New York, NY.

Crawford, W. and Gorman, M. (1995), Future Libraries: Dreams, Madness, and Reality, American Library Association, Chicago, IL.

Culler, J. (1976), Ferdinand de Saussure, Penguin Books, Harmondsworth.

Dunning, J. (1992), Booked to Die, Charles Scribner's Sons, New York, NY.

Fadiman, A. (1998), Ex Libris: Confessions of a Common Reader, Farrar, Straus and Giroux, New York, NY.

Gomez, J. (2008), Print is Dead: Books in Our Digital Age, Macmillan, London.

Google. (2011), "Google Books Library Project - An enhanced card catalog of the world's books", available at http://www.google.com/googlebooks/library.html (accessed 13 January 2012).

Gorman, M. (2000), Our Enduring Values: Librarianship in the 21st Century, American Library Association, Chicago, IL.

Haines, H. E. (1975), "A world of books", in McCrimmon, B. (Ed.), American Library Philosophy: An Anthology, Shoe String Press, Hamden, CT, pp. 141-149.

Harris, M. H. (1999), History of Libraries in the Western World (4th ed.), Scarecrow Press, Lanham, CT.

Herring, M. Y. (2005), "A gaggle of Googles: Limitations and defects of electronic access as panacea", in Miller, W. and Pellen, R. M. (Eds.), Libraries and Google ${ }^{\circledR}$, Haworth Press, Binghamton, NY, pp. 37-44.

Hill, S. (2010), Howard's End is on the Landing: A Year of Reading from Home, Profile Books, London. 
Hyde, D. (2005), "Sorites Paradox", available at http://plato.stanford.edu/entries/sorites-paradox (accessed 30 November 2011).

Jackson, M. (2008), Distracted: The Erosion of Attention and the Coming Dark Age, Prometheus Books, Amherst, NY.

Jeanneney, J-N. (2007), Google and the Myth of Universal Knowledge: A View from Europe, University of Chicago Press, Chicago, IL, (translated by Fagan, T.L.).

Johnson, M. (2010), This Book is Overdue! How Librarians and Cybrarians Can Save Us All, Harper, New York, NY.

Kelman, A. (2001), "The sound of the civic: Reading noise at the New York Public Library", in Augst, T. and Wiegand, W. A. (Eds.), The Library as an Agency of Culture, University of Wisconsin Press, Madison, WI, pp. 23-41.

Knuth, R. (2003), Libricide: The Regime-Sponsored Destruction of Books and Libraries in the Twentieth Century, Praeger, Westport, CT.

Lakoff, G. (1987), Women, Fire, and Dangerous Things: What Categories Reveal about the Mind, University of Chicago Press, Chicago, IL.

Latham, K. F. (2009), Numinous Experiences with Museum Objects, Ph.D. dissertation, Emporia State University, School of Library and Information Management, Emporia, NY.

Lerner, F. (1998), The Story of Libraries: From the Invention of Writing to the Computer Age, Continuum, New York, NY.

MacLeish, A. (1975), "The premise of meaning", in McCrimmon, B. (Ed.), American Library Philosophy: An Anthology, Shoe String Press, Hamden, CT, pp. 229-235.

Manguel, A. (1996), A History of Reading, Viking, New York, NY.

Manguel, A. (2004), A Reading Diary: A Passionate Reader's Reflections on a Year of Books, Farrar, Straus and Giroux, New York, NY.

Manguel, A. (2006), The Library at Night, Yale University Press, New Haven, CT.

Manguel, A. (2010), A Reader on Reading, Yale University Press, New Haven, CT.

McDade, T. (2006), The Book Thief: The True Crimes of Daniel Spiegelman, Praeger, Westport, CT.

McMurtry, L. (2008), Books: A Memoir, Simon \& Schuster, New York, NY.

Otto, R. (1958), The Idea of the Holy, Oxford University Press, London (translated by Harvey, J.W.).

Pawley, C. (2007), "Blood and thunder on the bookmobile: American public libraries and the construction of 'the reader' 1950-1995", in Augst, T. and Carpenter, K. (Eds.), Institutions of 
Reading: The Social Life of Libraries in the United States, University of Massachusetts Press, Amherst, MA, pp. 264-282.

Powell, L. C. (1958), A Passion for Books, World Publishing, Cleveland, OH.

Sandler, M. (2005), "Disruptive beneficence: The Google Print program and the future of libraries", in Miller, W. and Pellen, R. M. (Eds.), Libraries and Google ${ }^{\circledR}$, Haworth Press, Binghamton, NY, pp. 522.

Singer. P. (2011), "A Universal Library," available at http://www.project syndicate.org/commentary/singer73/English (accessed 18 January 2011).

Weinberger, D. (2007), Everything Is Miscellaneous: The Power of the New Digital Disorder, Times Books, New York, NY.

Wittgenstein, L. (1961), Tractatus Logico-Philosophicus, Routledge \& Kegan Paul, New York, NY, (translated by Pears, D. and McGuinness, B.).

Wittgenstein, L. (2001), Philosophical Investigations (3rd ed.), Blackwell, Malden, MA, (translated by Anscombe, G.).

Yumi, K. (2010), Library Wars: Love \& War (Vol. I), VIZ Media, San Francisco, CA. 